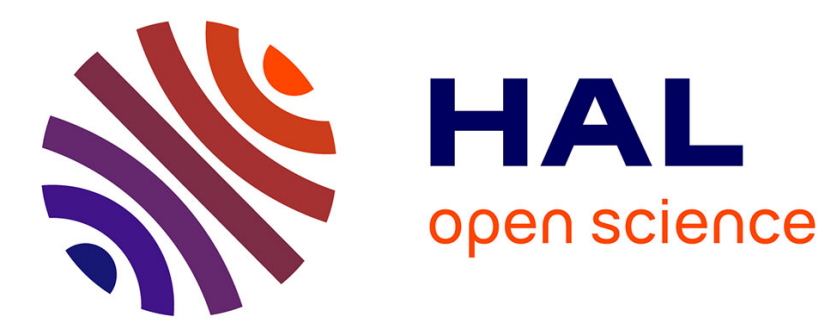

\title{
Reactions of the macrofauna of a forest mull to experimental perturbations of litter supply
}

Jean-François David, Jean-François Ponge, Pierre Arpin, Guy Vannier

\section{To cite this version:}

Jean-François David, Jean-François Ponge, Pierre Arpin, Guy Vannier. Reactions of the macrofauna of a forest mull to experimental perturbations of litter supply. Oikos, 1991, 61 (3), pp.316-326. $10.2307 / 3545239$. hal-00506973

\section{HAL Id: hal-00506973 https://hal.science/hal-00506973}

Submitted on 28 Oct 2010

HAL is a multi-disciplinary open access archive for the deposit and dissemination of scientific research documents, whether they are published or not. The documents may come from teaching and research institutions in France or abroad, or from public or private research centers.
L'archive ouverte pluridisciplinaire HAL, est destinée au dépôt et à la diffusion de documents scientifiques de niveau recherche, publiés ou non, émanant des établissements d'enseignement et de recherche français ou étrangers, des laboratoires publics ou privés. 


\title{
Reactions of the macrofauna of a forest mull to experimental perturbations of litter supply
}

Jean-François David, Jean-François Ponge, Pierre Arpin, and Guy Vannier

URA 689 CNRS, Laboratoire d'Ecologie Générale, Museum national d'Histoire naturelle, 91800 Brunoy, France.

\begin{abstract}
The effects on forest soil macrofauna of two treatments, viz. litter interception and twofold litter supply, were studied for five yr in the field. Results concern five saprophagous groups (Lumbricidae, Diplopoda, Isopoda, Coleoptera larvae, Diptera larvae) and five zoophagous groups (Geophilomorpha, Lithobiomorpha, Pseudoscorpionida, Coleoptera larvae, Diptera larvae). The litter interception had a negative effect on the abundance of most taxa, but was rather slow; there was no significant decrease in abundance before at least 1 yr in Lumbricidae, $2 \mathrm{yr}$ in lsopoda and zoophagous Diptera larvae, $2.5 \mathrm{yr}$ in Diplopoda, saprophagous Diptera larvae, Geophilomorpha and Lithobiomorpha. The twofold litter supply had no significant effect on the abundance of most taxa; on the other hand, it initiated a process of dead leaf accumulation in relation to control, with an annual decomposition rate ( $\left.\mathrm{k}^{\prime}\right)$ higher on the control plot than on the plot with an increased litter supply. The results do not support the assumption that saprophagous soil macrofauna are food-limited in acid mull conditions.
\end{abstract}

Many perturbation experiments have been carried out on soil ecosystems, in particular by adding insecticides or fertilizers (provision al review in Usher et al. 1982). Experiments consisting of modifications in litter supply, in order to investigate the reactions of the soil fauna to these perturbations, have been less numerous. Nielsen and Hole (1964), Uetz (1979), Hövemeyer (1989), Garay and Hafidi (1990), Judas (1990), Poser (1990) can be quoted for macrofauna, and Gill (1969), Stanton (1979), Arpin et al. (1985) for meso- and microfauna. In 1984, the latter authors began another study on the effects of the amount of litter and herbs on the meso- and microfauna of a forest mull, in a site more acidic than that formerly studied, where the annual litter fall was thought to be of greater importance owing to the lower organic matter content of the soil. This has given an opportunity for measuring the variations in abundance of the soil macrofauna in the same site, after decrease or increase in litter supply, which is the subject of the present paper. 
This kind of perturbation provides some information on (a) the reaction time of different taxa, and (b) the importance of the amount of food in community dynamics. For the question of whether some resources food in particular - limit saprophagous populations in the field, and whether there is competition or not for these resources, has not been solved for thirty years (cf. Hairston et al. 1960, Ehrlich and Birch 1967, Slobodkin et al. 1967). In Isopoda, for example, Warburg et al. (1984) think that population dynamics is primarily controlled by climatic factors, whereas Rushton and Hassall (1987) are of the opinion that there is density-dependent regulation due to competition for the best quality food. In addition, Van der Drift (1963) and Anderson and Healey (1972) consider that the amount of available food may vary greatly from year to year, between limiting conditions and excess resource. Experiments modifying the litter supply in forest cannot settle those questions decisively, for too many factors escape control; nevertheless, they are interesting insofar as they test the conflicting hypotheses under natural conditions.

\section{Study site and methods}

\section{Site description}

The study site is located in parcel No. 921 of the Ingrannes Massif, in the State forest of Orleans, France. Temperature fluctuates between $0.2^{\circ} \mathrm{C}$ (average minimum in January) and $23.9^{\circ} \mathrm{C}$ (average maximum in July), and annual rainfall, rather evenly distributed, amounts to $624 \mathrm{~mm}$ (regional averages from 1951 to 1980).

The forest stand consists mainly of oak (Quercus petraea), which gives $87 \%$ of the mass of dead leaves, with a little beech (Fagus sylvatica) and hornbeam (Carpinus betulus). The herb layer, not very developed, consists mainly of bramble (Rubus schleicheri).

The humus is an acid mull ( $\mathrm{pH}=5.2$ ), with $\mathrm{AoL}$ and AoF layers 0.5 to $1 \mathrm{~cm}$ and 0.2 to $0.5 \mathrm{~cm}$ thick respectively. The percentage of organic matter in the A1 layer is low (3.3\%), as is its $\mathrm{C} / \mathrm{N}$ ratio (13.2).

The soil is a leached brown earth, with a temporary water table which is usually more than $1 \mathrm{~m}$ deep, but can rise to $14 \mathrm{~cm}$ below ground level during rainy winters. The silty texture of the upper soil layer reduces its drying capacity in summer; the mean soil moisture was $15 \%$ from July to September 1985 , a figure to be compared to $22 \%$ for the field capacity $(\mathrm{pF}=2.5)$ and $6 \%$ for the wilting point $(\mathrm{pF}=4.2)$ 


\section{Perturbations of organic matter supply}

The first part of the study site $(12 \times 6 \mathrm{~m})$ was covered in February 1985 with $1 \mathrm{~m}^{2}$ detachable baskets made of 1 $\mathrm{cm}^{2}$ plastic mesh, set $50 \mathrm{~cm}$ above ground level. This area was divided into four $6 \mathrm{x} 3 \mathrm{~m}$ plots, corresponding to four treatments pursued fortnightly until September 1990:

(a) LoHo plot. Baskets turned upside down (normal litter supply) and herb layer undamaged.

(b) LoH-plot. Baskets turned upside down (normal litter supply) and herb layer cut away.

(c) L-Ho plot. Baskets emptied outside the plot (decrease in litter supply) and herb layer undamaged.

(d) $L-H-$ plot. Baskets emptied outside the plot (decrease in litter supply) and herb layer cut away.

The second part of the study site $(4 \times 4 \mathrm{~m}), 6 \mathrm{~m}$ away from the first one and without baskets, was supplied from the autumn of 1985 with the litter of sixteen baskets from the L- plots, in addition to normal litter fall. This part was the $L+$ plot, and the herb layer was left undamaged.

Some remarks are necessary about the treatments:

(a) Taking into account the phenology of litter fall, litter interception $\left(\mathrm{L}^{-}\right)$actually began in the autumn of 1985.

(b) The L-treatment was a drastic decrease in litter supply, but the mesh let through leachates and small solid debris from canopy. In addition, there were other inputs of organic matter on the L- plots, such as dead leaves from the herb layer on the L-Ho plot, and also algae and moss which developed on the bare ground.

(c) The cutting of the herb layer $\left(\mathrm{H}^{-}\right)$led to its decay in a few months. Therefore, its influence was progressively suppressed on the H- plots from the autumn of 1985 , as the decay of roots proceeded.

(d) The L+ treatment was nearly equivalent to a doubling of litter supply from canopy, except for the small debris.

\section{Measurements of litter amounts}


The annual litter fall and its spatial variation within the site were estimated by weighing air-dried dead leaves, dead wood and fruits, collected fortnightly in twelve baskets taken at random on the L- plots. These measurements were made for three years, from mid-September 1985 to mid-September 1988.

The parameter k' of Jenny et al. (1949), which is equal to the average fraction of litter which disappears from the ground annually, was estimated on the Lo and L+ plots at the end of the experiment. For this purpose, seven 1/16 $\mathrm{m}^{2}$ sampling units were taken in September 1990, cleaned of mineral particles and air-dried, in order to measure the mass of old litter $(\mathrm{F})$ just before the fall; k' was calculated as $\mathrm{k}^{\prime}=\mathrm{A} /(\mathrm{A}+\mathrm{F})$, where $\mathrm{A}$ is the mean annual litter fall.

\section{Faunal sampling}

Sampling of the whole soil macrofauna, deep burrowing earthworms included, requires destructive methods, which were used only for the last sample, in the spring of 1990. Earlier in the experiment, $10 \mathrm{~cm}$ deep probes were taken twice a year, in spring and autumn; from the autumn of 1984 to the spring of 1989 on the LoHo, LoH-, L-Ho and L-H- plots, and from the autumn of 1985 to the spring of 1989 on the L+ plot. The sampling units (s. u.) were as small as possible in order to limit disturbance of the study site. At first they were taken with a $10 \mathrm{~cm}$ cubic corer $\left(1 / 100 \mathrm{~m}^{2}\right)$ in the autumn of 1984 , and subsequently with a cylindrical corer $10 \mathrm{~cm}$ in diameter $\left(1 / 127.3 \mathrm{~m}^{2}\right)$. On each sampling occasion, 5 s.u. per plot were taken at random without replacement, but not processed separately. Invertebrates were extracted using Tullgren funnels.

For the last sample, in the spring of 1990 , each s. u. was taken as follows: the litter and the upper soil layer were taken in a $1 / 11 \mathrm{~m}^{2}$ quadrat, and then transferred to Tullgren funnels. The same depth of soil was removed from a $1 / 4 \mathrm{~m}^{2}$ quadrat, and 51 of $0.3 \%$ formaldehyde solution was then applied to this area to expel the deep soil macrofauna. 51 of $0.4 \%$ and $0.5 \%$ solution were added at 10 minute intervals, and the underlying soil was finally dug from a $1 / 11 \mathrm{~m}^{2}$ quadrat to sort invertebrates by hand on a cloth. 7 s.u. per plot were taken at random, on the same days for all the plots, and processed separately. All the saprophagous invertebrates were weighed in the laboratory to estimate the fresh biomass of litter-feeding macrofauna.

\section{Statistical analysis}


The abundance data were log transformed, in order to reduce departures from the basic assumptions of the statistical tests used, viz. normality and homogeneity of variance. However, the tests were considered to be robust to departures from normality (Sokal and Rohlf 1981).

In order to compensate for lack of spatial replication of treatments, making it possible to take into account spatial heterogeneity in the data analysis, the homogeneity of abundances on the plots before treatment can be checked. A set of one-factor analyses of variance (ANOVA) in blocks was carried out on the data obtained before any effect of perturbations could be determined, i.e. from the autumn of 1984 to the autumn of 1985. The different sampling occasions were treated as blocks, so as to separate temporal variation from variation due to the plots. Owing to the fact that there were no data for the $\mathrm{L}+$ plot in the autumn of 1984 and spring of 1985, the first data collected in the autumn of 1985 were compared to the mean of the other four plots by t-tests.

A set of two-factor ANOVA in blocks was carried out to compare the abundances on the LoHo, LoH-, L-Ho and L-H- plots, for different periods from the spring of 1986 to the spring of 1990. The two factors were the interception of litter and the cutting of the herb layer; the sampling occasions were treated as blocks. The abundances on the same plots in the last sample, in the spring of 1990, were also compared with the help of twofactor ANOVA.

A set of one-factor ANOVA in blocks was carried out to compare the abundances under three levels of litter supply (Lo, L-, L+), for different periods from the spring of 1986 to the spring of 1990. As the cutting of the herb layer, tested beforehand, had no significant effect on the abundance of taxa, all the values obtained for the Lo and L- plots were included in the analyses, whether there was a herb layer or not. The abundances under the three levels of litter supply in the last sample, in the spring of 1990, were also compared with the help of onefactor ANOVA. The differences between sample means were tested using the Student-Newman-Keuls procedure (SNK) at the $5 \%$ level of significance.

\section{Results}

\section{General data}


Ten taxa were studied throughout the experiment. Other taxa were not taken into account because they were either far less numerous, or considered too small in size on average to belong to the macrofauna. The main taxa can be roughly divided into saprophages and zoophages, feeding primarily on plant debris or prey respectively. The first group includes:

(a) Lumbricid earthworms, with nine determined species (epigeic Lumbricus castaneus and L. rubellus; anecic Lumbricus centralis, L. festivus and Nicodrilus giardi; endogeic Allolobophora chlorotica, A. rosea, Nicodrilus caliginosus and Octolasium cyaneum).

(b) Iulid, Glomerid and Polydesmid Diplopoda, with six determined species (Allajulus londinensis, A. nitidus, Tachypodoiulus niger, Glomeris intermedia, G. marginata and Polydesmus angustus).

(c) Isopoda.

(d) Elaterid and Tenebrionid larvae (Coleoptera).

(e) Bibionid, Muscid (Fannia sp.), Sciarid, Tipulid (except Limoniinae) and Trichocerid larvae (Diptera).

The zoophagous group includes:

(a) Geophilomorph Chilopoda.

(b) Lithobiomorph Chilopoda.

(c) Pseudoscorpionida.

(d) Carabid, Lampyrid and Staphylinid larvae (Coleoptera).

(e) Asilid, Rhagionid and Tipulid (Limoniinae only) larvae (Diptera).

The insect larvae were highly dominant in number (44\% of the total number of individuals collected on the Lo plots), even omitting the exceptional abundance of Bibionid larvae in one s.u., the autumn of 1985. Other numerous groups were Lumbricidae (16\%) and both orders of Chilopoda (11\% each), before Diplopoda (7\%), Pseudoscorpionida (6\%) and Isopoda (5\%). Due to the high average individual biomass within the taxa (cf. Petersen and Luxton 1982 for dry masses), Lumbricidae were highly dominant, coming far before Diplopoda and Chilopoda. Actual measurements of fresh biomass on the Lo plots in the spring of 1990 gave $28.6 \pm 2.9$ (s.e.) g $\mathrm{m}^{-2}$ for Lumbricid earthworms, $3.8 \pm 1 \mathrm{~g} \mathrm{~m}^{-2}$ for Diplopoda, and less than $0.3 \mathrm{~g} \mathrm{~m}^{-2}$ for other saprophagous 
groups.

The variation in abundance in time, irrespective of any treatment effect, was substantial in most taxa and in the soil macrofauna as a whole (Fig. 1). On the one hand, there was some seasonal periodicity, showing maxima in autumn and minima in spring; on the other hand, there was great variation according to year, which can be ascribed both to chance as regards the sampling conditions, and to real year-to-year fluctuations in community abundance. The last sample, taken in the spring of 1990 with the purpose of collecting the soil macrofauna more completely than in probes, actually gave low densities for most taxa. In this particular case, the decrease in abundance might also be due to the change of sampling methods.

\section{Litter amounts}

The results of litter fall measurements on the $\mathrm{L}^{-}$plots are given in Table 1 . The annual mean was $648 \mathrm{~g} \mathrm{~m}^{-2}$ for the total litter and $423 \mathrm{~g} \mathrm{~m}^{-2}$ for dead leaves only. Year-to-year fluctuations were about $10 \%$. The dispersion of the measures, as given by the standard error of the mean in Table 1, shows that litter fall was heterogeneous as regards dead wood and fruits, but very homogeneous as regards dead leaves. This allows dead leaf quantities to be extrapolated to the whole site. It will be admitted that (a) the annual leaf litter supply was $423 \mathrm{~g} \mathrm{~m}^{-2}$ on the Lo plots, equalling the quantity removed from the $\mathrm{L}^{-}$plots; (b) the annual leaf litter supply was $2 \times 423=846 \mathrm{~g} \mathrm{~m}^{-2}$ on the L+ plot.

After five years of treatments, in September 1990, the mass of litter on the ground before the fall was $508 \pm 44 \mathrm{~g} \mathrm{~m}^{-2}$ and $1505 \pm 118 \mathrm{~g} \mathrm{~m}^{-2}$ on the Lo and L+ plots respectively, which leads to a $\mathrm{k}^{\prime}$ value higher on the control plots for litter supply (0.56) than on the plot with an increased litter supply (0.46). For dead leaves only, the mass on the ground before the fall was $296 \pm 38 \mathrm{~g} \mathrm{~m}^{-2}$ and $744 \pm 38 \mathrm{~g} \mathrm{~m}^{-2}$ on the Lo and L+ plots respectively, which also leads to a k' value higher on the control plots ( 0.59 vs 0.53$)$. On the $\mathrm{L}^{-}$-plots, nearly the whole of the litter layer had disappeared, the ground growing bare from the spring of 1987.

\section{Variations in soil macrofauna abundance after perturbations}

\section{Initial data}

The results of ANOVA carried out to check the homogeneity of abundance of taxa before treatments are given in 
Table 2. In view of the small number of sampling occasions (three blacks between the autumn of 1984 and the autumn of 1985), the power of the tests is low and there is some risk of type II errors. However, in any taxon, abundance appears homogeneous on the four plots covered with baskets ( $\mathrm{LoHo}, \mathrm{LoH}-$, L-Ho and $\mathrm{L}-\mathrm{H}-)$; the probability that the four samples were drawn from the same population is generally high $(\mathrm{P} \geq 0.21)-$ except for zoophagous Coleoptera larvae, and saprophagous Diptera larvae owing to their outstandingly contagious distribution $(\mathrm{P}=0.06)$.

Table 2 also gives the results of t-tests comparing the first sample from the L+ plot with those from the other four plots for the autumn of 1985 . They show that, in any taxon, the probability that the L+ estimate was from the same normal distribution as the other sample means is high $(\mathrm{P} \geq 0.19)$.

Effects of herb layer removal

ANOVA of the data obtained between the spring of 1986 and the spring of 1990 on the LoHo, LoH-, L-Ho and $\mathrm{L}-\mathrm{H}-$ plots, show that no significant effect of cutting the herb layer can be found in the studied taxa, for any peri ad analysed (Table 3). This contrasts strongly with the effect of the decrease in litter supply, when tested for the same periods.

The result is confirmed by ANOVA on the data from the last sample, in the spring of 1990, both expressed as number of individuals or biomass. On this sampling occasion, only one taxon - Lithobiomorpha was significantly less abundant where the herb layer had been removed, and on one $\mathrm{H}-$ plot only (interaction with the other treatment is significant).

The simplest interpretation of this result is that herb layer has little influence on the soil macrofauna of the studied site, and its presence or absence can be disregarded when studying the effects of litter supply.

\section{Effects of changes of litter supply}

The variations in the abundance of taxa through time for three levels of litter supply (Lo, $\left.\mathrm{L}_{-}, \mathrm{L}+\right)$ are represented in Figs 2 and 3. The time at which a treatment began to produce an effect can be determined graphically, and ANOVA of data obtained from this time onwards makes it possible to test the significance of the apparent heterogeneity (Table 4). 
In many taxa, abundance was significantly decreased on the L- plots, while there was no significant difference between the Lo and L+ plots. This result concerns Lumbricidae, Diplopoda, Isopoda and Diptera larvae among saprophagous groups, and Geophilomorpha, Lithobiomorpha, Coleoptera larvae and Diptera larvae among zoophagous groups. In the case of Diplopoda, the significance level is barely reached, and the result is only based on the least significant difference (LSD), not on the SNK procedure. The effect seems to have begun:

(a) as early as the spring of 1986 in zoophagous Coleoptera larvae;

(b) in the autumn of 1986 in Lumbricidae, though becoming much more evident in the autumn of 1987 (in both cases $\mathrm{P}<0.001)$;

(c) in the autumn of 1987 in Isopoda and zoophagous Diptera larvae;

(d) in the spring of 1988 in Diplopoda, saprophagous Diptera larvae, Lithobiomorpha, and in the spring or autumn of 1988 in Geophilomorpha (in both cases $\mathrm{P}<0.001$ ).

The perturbations acted differently on the other two taxa. The abundance of saprophagous Coleoptera larvae was significantly increased and that of Pseudoscorpionida was significantly decreased on the L+ plot, but there was no significant difference between the Lo and L- plots. The effect seems to have begun in the autumn of 1986 in saprophagous Coleoptera larvae and in the spring of 1987 in Pseudoscorpionida.

ANOVA of data from the last sample, in the spring of 1990, confirm the results of the treatment effects for most taxa (Lumbricidae, Diplopoda, Isopoda, saprophagous Diptera larvae, Geophilomorpha, Lithobiomorpha), regarding individual numbers as well as biomass. On this definite sampling occasion, other taxa showed a distribution somewhat different, though not inconsistent with their previous trends.

\section{Discussion}

\section{Effects of decrease in litter supply}

The comparison between the control plots, with a normal litter supply (Lo), and the plots where litter was intercepted $\left(\mathrm{L}^{-}\right)$shows that the existence of many taxa in the soil macrofauna depends, directly or indirectly, on litter. Whereas their abundance on the different plots showed no significant heterogeneity before treatment, the perturbation resulted in a drop in individual numbers and biomass. That was the case not only for saprophagous 
groups (Lumbricidae, Diplopoda, Isopoda, Diptera larvae), but also for zoophagous groups as far as individual numbers are concerned (Geophilomorpha, Lithobiomorpha, Coleoptera and Diptera larvae). Such a result, which confirms those in the literature (Nielsen and Hole 1964, Hövemeyer 1989, Garay and Hafidi 1990, Judas 1990, Poser 1990), may seem trivial. However, an important point is that, in most cases, there was no close dependence on the most recent litter fall. In saprophagous groups in particular, decrease in abundance was usually evident only after two yr since the perturbation started: for example, after $2 \mathrm{yr}$ in Isopoda; after $2.5 \mathrm{yr}$ in Diplopoda and Diptera larvae; and the decrease was more pronounced after 2 yr in Lumbricidae (cf. Fig. 2).

The reaction time of the main components of the soil macrofauna coincided approximately with the beginning of litter disappearance on the L- plots. It was a gradual process, which cannot be dated precisely, but the soil began to become bare from the spring of 1987 onwards, i.e. $1.5 \mathrm{yr}$ after the perturbation had started. When the amount of litter on the ground became very small, the soil community was likely to be influenced, a priori, by three sorts of factors:

(a) Microclimatic factors. The buffer action of litter towards temperature and moisture fluctuations no longer existed on the L- plots, and some light directly reached the soil.

(b) Trophic factors. Litter-feeding populations were deprived of food on the L- plots; the case of zoophagous groups is less clear, because they feed mainly on mesofauna, for which data are not yet available.

(c) Structural factors. The complexity of litter, which affects the abundance of some predators (Bultman and Uetz 1984), was lowered on the L- plots.

There is no objective means of separating the influence of these different factors in our experiment, but it can be affirmed that, in most cases, they did not act after the very first interception of litter. In case of stress as soon as the first interception, the members of the soil macrofauna would have responded by a decrease in abundance owing to the fact that they are very mobile, as shown by pitfall trapping.

This implies that saprophagous groups do not feed, or feed very little, on litter lying on the ground for less than $1 \mathrm{yr}$, but depend primarily on the most decomposed debris. This is in accordance with results of feeding behaviour experiments, which show that many species of the soil macrofauna (except in some Isopoda), prefer to eat dead leaves from lower litter layers (Van der Drift 1951, Kheirallah 1979, Soma and Saito 1983, David 1986). It follows that the saprophagous macrofauna feed on the organic matter reduced by leaching, activity of 
mesofauna, microfauna and microflora, and thus much below $423 \mathrm{~g} \mathrm{~m}^{-2}$, the mean annual leaf fall.

\section{Effects of increase in litter supply}

Dead leaves and associated microflora are actively eaten by many species of the forest soil macrofauna. Therefore, an increase in litter supply constitutes undeniably an increase in food for saprophagous populations even if the additional food is not directly available and does not equal the amount of dead leaves which are added (see above).

However, the comparison between the control plots (Lo) and the plot with a twofold litter supply (L+) shows that this treatment had no effect on the abundance of the main taxa. Only the abundance of saprophagous Coleoptera larvae, a group of minor importance with respect to biomass, was significantly increased on the L+ plot; and, though this observation is in accordance with the natural distribution of Elaterid larvae in thick litter layers (Bornebusch 1930), one cannot be certain that it is due to the increase in litter supply. In this particular case, the lack of baskets on the plot makes the comparison difficult, as egg-laying conditions were not the same as on the Lo and $\mathrm{L}-$ plots for winged adult insects. In all the other saprophagous groups, abundance did not deviate significantly from the control value. Not only was there no significant difference between individual numbers and biomasses on the Lo and L+ plots in the last sample ( $4.5 \mathrm{yr}$ after the treatment had started), but also the variations in abundance through time were remarkably similar on both kinds of plots (cf. Fig. 2).

As regards the question of the amount of resource at the disposal of the macrofauna in mull conditions, this outcome may be interpreted in several ways.

(a) According to the simplest interpretation, there is no limiting resource and the abundance of populations is controlled by density-independent factors. This assumption is reinforced by the fact that closely related species, with regards to both taxonomy and feeding habits, were often found in the same sampling unit; for instance, Glomeris marginata and G. intermedia in Diplopoda, Lumbricus centralis and L. festivus in anecic earthworms.

However, given this interpretation, it must be explained why there is apparently no litter accumulation in the mull site. If the saprophagous soil macrofauna are not food-limited, how is it that excess food does not accumulate year by year? There are two possible answers to this argument, frequently discussed after Slobodkin 
et al. (1967).

(1) The first one, which is not at variance with the last authors' opinion, is that food uneaten by macrofauna would be utilized by other communities in the site, such as soil mesofauna, or fungal and bacterial microflora, the real decomposers; these communities would be saturated and food-limited, as assumed by Vannier (1985) in mesofauna, but the soil macrofauna would not.

(2) The second one is that no soil community would be food-limited, and that, logically, organic matter would be in excess in forest soils; but while that could lead to some perceptible accumulation in mor sites where the excess litter is considerable (Van der Drift 1963), it would not be the same in mull sites; first because the excess, if any, is presumably slighter; secondly because accumulation, in ecosystems which are not closed, may be delayed or balanced by organic matter exports, notably by drainage.

Therefore, the assumption that the soil macrofauna, or even the whole decomposer community, is controlled by density-independent factors, cannot be ruled out. It would even be unquestionable if the variations in abundance through time on the Lo and L+ plots really represented year-to-year fluctuations. The extent of the variation in abundance of Lumbricidae, for example, would imply that they were below the carrying capacity of the environment for most of the time. Unfortunately, it is not evident that the variations observed in probes were real year-to-year fluctuations.

(b) According to a second interpretation - compatible with the results if the variations in abundance through time could be ascribed to sampling conditions - space would be the major limiting factor, with the soil macrofauna being already saturated with individuals. This assumption would explain why the abundance of the main taxa did not increase significantly, in spite of an additional food supply. However, this is not very realistic, owing to the fact that higher biomasses and individual numbers have been measured in other forest mull communities (Bornebusch 1930, Petersen and Luxton 1982).

(c) Finally, the assumption that food would be the limiting factor cannot be completely discarded, but with the condition that other changes brought about by the increase in litter thickness had negative effects, balancing the positive effect of the increase in food supply. Though this more complicated process is also more unlikely, there is at least one reason for not precluding it. When the increase in litter supply was more extreme than in our experiment, a negative effect was effectively observed, in Lumbricidae in particular (Judas 1990), which gives weight to the idea that opposing influences may govern the resulting abundance of macrofauna. This 
would also lead to regard the conflicting conclusions in the literature as equally plausible, the equilibrium abundance after perturbation changing according to conditions and populations involved. For instance, Nielsen and Hole (1964) found that a twofold litter supply resulted in twice as much Lumbricid activity, preventing any accumulation; the same perturbation had no effect on the abundance of Lumbricidae in our experiment, whereas Judas (1990) found that abundance decreased after two successive fivefold increases in litter supply. Under the last conditions, Hövemeyer (1989) found that the abundance of saprophagous Diptera larvae increased, whereas a twofold litter supply had no effect on them in our experiment.

A negative effect is very unlikely to have originated in an increase in predation on the L+ plot. Predators capable of feeding, at least in part, on saprophagous macrofauna - such as Chilopoda (Poser 1988) were not significantly more numerous than on the control plots. Further studies are in progress in order to detect possible noxious factors associated with the thicker litter layer on the L+ plot, notably from the chemical point of view. But it could be very difficult to prove that food is a limiting factor in forest mull communities, if other factors actually tend to inhibit the effect of an increment in food supplies.

\section{Soil saprophagous macrofauna and processes of litter decomposition}

The five-yr treatment on the L+ plot clearly initiated a process of dead leaf accumulation in relation to the control plots. The difference between the k' values for dead leaves of the L+ and Lo plots, 0.53 and 0.59 respectively, reflects that process, which is even more pronounced if the whole litter is taken into account, dead wood included.

However, in a forest mull with soil macrofauna in abundance, k' should not be regarded as the parameter of a simple exponential model of decomposition, in which litter would lose a fairly constant percentage of mass per year. The measured k' value results from several decomposition processes (Witkamp and Olson 1963):

(a) Microprocesses (consumption by microfauna and mesofauna, microbial decomposition, leaching), the effects of which may approximate, more or less, to an exponential model, as in fine mesh bag experiments (Anderson 1973, Lousier and Parkinson 1976, Berg and Wessén 1984).

(b) A removal of dead leaves by mull macrofauna, at a given time during decomposition, for example 1 
or 2 years after litter fall; the term removal underlines the fact that soil macrofauna not only break down leaf litter in faeces (Macroarthropoda, epigeic and anecic Lumbricidae, Gastropoda), but also mix faeces in the A1 layer (endogeic and anecic Lumbricidae); anecic Lumbricidae also bury complete leaves in the soil, without eating (e.g. Satchell and Lowe 1967, Szlavecz 1985).

It is quite possible that the microprocesses of litter decomposition were enhanced on the L+ plot, due to microclimatic changes connected with litter thickness (Dwyer and Merriam 1981). In spite of this, dead leaves accumulated on this plot in relation to the control. This is to be compared with the fact that the abundance of saprophagous macrofauna was not higher on the L+ than on the Lo plots during the experiment, in both individual numbers and biomass, from which it can be inferred that the same amount of leaf litter was removed annually by the soil macrofauna on both kinds of plots. The dead leaf accumulation on the L+ plot in relation to the control may therefore have been due to the discrepancy between litter supply and consumption by saprophagous macrofauna, however high the decomposition due to microprocesses may have been.

\section{Conclusions}

The saprophagous macrofauna of acid mull in a temperate forest feeds primarily on litter lying on the ground for more than one year. Taking into account decomposition and leaching which occur until the time when litter is consumed, the mass of available food is appreciably lower than the mass of litter fall.

In spite of this, there is no evidence of food being a limiting factor in the main taxa of saprophagous macrofauna. The community, when followed through $4.5 \mathrm{yr}$, does not respond to an increase in litter supply by an increase in abundance, either in individual numbers or in biomass. The implicit acceptance of some exploitation competition in soil macrofauna communities (either intraspecific or interspecific if several species feed on the same resource) is, at least, hazardous.

A twofold litter supply results in an accumulation process, in relation to control conditions, which is likely to be caused by the inability of the soil macrofauna to eat or remove the additional food supply.

Acknowledgements - We are very grateful to H. Read for having checked the English text. We are indebted to F. Arpin, R. Botalla, M. Dolin and A. Munsch (C.N.R.S., URA 689) for their technical cooperation. 


\section{References}

Anderson, J.M. 1973. The breakdown and decomposition of sweet chestnut (Castanea sativa Mill.) and beech (Fagus sylvatica L.) leaf litter in two deciduous woodland soils. - Oecologia (Berl.) 12: 251-274.

- and Healey, I.N. 1972. Seasonal and inter-specific variation in major components of the gut contents of some woodland Collembola. - J. Anim. Ecol. 41: 359-368.

Arpin, P., Kilbertus, G., Ponge, J.F., Vannier, G. and Verdier, B. 1985. Réactions des populations animales et microbiennes du sol à la privation des apports annuels de litière: exemple d'une rendzine forestière. Bull. Ecol. 16: 95-115.

Berg, B. and Wessén, B. 1984. Changes in organic-chemical components and ingrowth of fungal mycelium in decomposing birch leaf litter as compared to pine needles. - Pedobiologia 26: 285-298.

Bornebusch, C.H. 1930. The fauna of forest soil. - Forst. Fors. Vaes. Danm. 11: 1-244.

Bultman, T.L. and Uetz, G.W. 1984. Effect of structure and nutritional quality of litter on abundances of litterdwelling Arthropods. - Am. Midl. Nat. 111: 165-172.

David, J.F. 1986. Influence de la durée du séjour dans la litière des feuilles mortes de chêne (Quercus petraea Liebl.) sur leur consommation par le Diplopode Cylindroiulus nitidus (Verhoeff, 1891). - C.R. Acad. Sc. Paris Sér. III 302: 7-10.

Dwyer, L.M. and Merriam, G. 1981. Influence of topographic heterogeneity on deciduous litter decomposition. Oikos 37: 228-237.

Ehrlich, P.R. and Birch, L.C. 1967. The "balance of Nature” and "population control”. - Am. Nat. 101: 97-107.

Garay, I. and Hafidi, N. 1990. Study of a mixed forest litter of hornbeam (Carpinus betulus L.) and oak (Quercus sessiliflora Smith) III. Organization of the edaphic macroarthropod community as a function of litter quantity. - Acta Oecologica 11: 43-60.

Gill, R.W. 1969. Soil microarthropod abundance following old-field litter manipulation. - Ecology 50: 805-816.

Hairston, N.G., Smith, F.E. and Slobodkin, L.B. 1960. Community structure, population control and 
competition. - Am. Nat. 94: 421-425.

Hövemeyer, K. 1989. Der Einflu $\beta$ von Streumenge und Streuqualität auf die Siedlungsdichte von Dipterenlarven: ein Freilandexperiment im Kalkbuchenwald. - Verh. Ges. Okol. 17: 229-236.

Jenny, H., Gessel, S.P. and Bingham, FT. 1949. Comparative study of decomposition rates of organic matter in temperate and tropical regions. - Soil Sci. 68: 419-432.

Judas, M. 1990. The development of earthworm populations following manipulation of the canopy leaf litter in a beechwood on limestone. - Pedobiologia 34: 247-255.

Kheirallah, A.M. 1979. Behavioural preference of Iulus scandinavius (Myriapoda) to different species of leaf litter. - Oikos 33: 466-471.

Lousier, J.D. and Parkinson, D. 1976. Litter decomposition in a cool temperate deciduous forest. - Can. J. Bot. 54: 419-436.

Nielsen, G.A. and Hole, FD. 1964. Earthworms and the development of coprogenous A1 horizons in forest soils of Wisconsin. - Soil Sci. Soc. Am. Proc. 28: 426-430.

Petersen, H. and Luxton, M. 1982. A comparative analysis of soil fauna populations and their role in decomposition processes. - Oikos 39: 288-388.

Poser, T. 1988. Chilopoden als Prädatoren in einem Laubwald. - Pedobiologia 31: 261-281.

- $\quad$ 1990. The influence of litter manipulation on the centipedes of a beech wood. - In: Minelli, A. (ed .), Proc. 7th. int. Congr. Myriapod. Brill, Leiden, pp. 235-245.

Rushton, S.P. and Hassall, M. 1987. Effects of food quality on isopod population dynamics. - Funct. Ecol. 1: $359-367$.

Satchell, J.E. and Lowe, D.G. 1967. Selection of leaf litter by Lumbricus terrestris. - In: Graff, O. and Satchell, J.E. (eds), Progress in soil biology. North Holl. Publ., Amsterdam, pp. 102-119.

Slobodkin, L.B., Smith, F.E. and Hairston, N.G. 1967. Regulation in terrestrial ecosystems and the implied balance of Nature. - Am. Nat. 101: 109-124.

Sokal, R.R. and Rohlf, F.J. 1981. Biometry, Freeman, New York. 
Soma, K. and Saito, T. 1983. Ecological studies of soil organisms with references to the decomposition of pine needles. II. Litter feeding and breakdown by the woodlouse Porcellio scaber. - Plant Soil 75: 139-151.

Stanton, N.L. 1979. Patterns of species diversity in temperate and tropical litter mites. - Ecology 60: $295-304$.

Szlavecz, K. 1985. The effect of microhabitats on the leaf litter decomposition and on the distribution of soil animals. - Holarct. Ecol. 8: 33-38.

Uetz, G.W. 1979. The influence of variation in litter habitats on spider communities. - Oecologia (Berl.) 40: $29-42$.

Usher, M.B., Booth , R.G. and Sparkes, K. 1982. A review of progress in understanding the organization of communities of soil arthropods. - Pedobiologia 23: 126-144.

Van der Drift, J. 1951. Analysis of the animal community in a beech forest floor. - Tijdschr. V. Entom. 94: $1-168$.

- 1963. The disappearance of litter in mull and mor in connection with weather conditions and the activity of the macrofauna. - In: Doeksen, J. and Van der Drift, J. (eds), Soil organisms. North Holl. Publ., Amsterdam, pp. 125-133.

Vannier, G. 1985. Modes d'exploitation et de partage des ressources alimentaires dans le système saprophage par les microarthropodes du sol. - Bull. Ecol. 16: 19-34.

Warburg, M.R., Linsenmair, K.E. and Bercovitz, K. 1984. The effect of climate on the distribution and abundance of Isopods. - Symp. Zool. Soc. Lond. 53: 339-367.

Witkamp, M. and Olson, J.S. ]963. Breakdown of confined and nonconfined oak litter. - Oikos 14: 138-147. 


\section{Legends of figures}

Fig. 1. Variations in abundance of the whole soil macrofauna through time. Data from the Lo plots. (A: Autumn. S: Spring. B.I.: Bibionid larvae separated from other saprophages).

Fig. 2. Variations in abundance of the saprophagous taxa through time, under three levels of litter supply: Lo (white squares), L- (black squares), L+ (triangles). (Vertical line: beginning of treatments. Arrow: beginning of effect to test. A: Autumn. S: Spring).

Fig. 3. Variations in abundance of the zoophagous taxa through time, under three levels of titter supply: Lo (white squares), L- (black squares), L+ (triangles). (Vertical tine: beginning of treatments. Arrow: beginning of effect to test. A: Autumn. S: Spring). 
Table 1. Average masses (g air-dried) of annual litter fall on the $\mathrm{L}-$ plots ( \pm standard error).

\begin{tabular}{lcccccc}
\hline Year & \multicolumn{4}{c}{ dead leaves } & dead wood and fruits & Total \\
\cline { 2 - 5 } & Oak & Beech & Hornbeam & Total & & \\
\hline Sept. 85-Sept. 86 & 339 & 31 & 29 & $399 \pm 4$ & $225 \pm 33$ & $625 \pm 34$ \\
Sept. 86-Sept. 87 & 386 & 30 & 19 & $435 \pm 5$ & $202 \pm 23$ & $637 \pm 23$ \\
Sept. 87-Sept. 88 & 376 & 39 & 19 & $434 \pm 6$ & $248 \pm 32$ & $683 \pm 35$ \\
Mean & 367 & 33 & 23 & 423 & 225 & 648 \\
\hline
\end{tabular}


Table 2. Statistical analysis of abundances before treatments. $P$ is the probability that the sample means are from the same population.

\begin{tabular}{llll}
\hline & $\begin{array}{l}\text { 1-factor anova in blocks on four plots with } \\
\text { baskets (autumn 84-autumn 85) }\end{array}$ & $\begin{array}{l}\text { t-test comparing L+ plot to other four } \\
\text { plots (autumn 85) }\end{array}$ \\
\cline { 2 - 2 } & P-value & P-value \\
\hline Lumbricidae & 0.21 & 0.63 \\
Diplopoda & 0.61 & 0.22 & 0.37 \\
Isopoda & 0.34 & 0.46 \\
sapro. Coleoptera 1. & 0.06 & 0.61 \\
sapro. Diptera 1. & 0.57 & 0.86 \\
Geophilomorpha & 0.33 & 0.19 \\
Lithobiomorpha & 0.65 & 0.81 \\
Pseudoscorpionida & 0.06 & 0.19 \\
zoo. Coleoptera 1. & 0.06 & 0.68 \\
zoo. Diptera 1. & 0.23 & 0.36 \\
\hline
\end{tabular}


Table 3. Statistical analysis of abundances under two treatments: litter interception (Lo vs $\mathrm{L}^{-}$) and herb-layer removal (Ho vs $\mathrm{H}^{-}$). $\mathrm{P}$ is the probability that the sample means are from the same population. The analysed period is the one that yields the lower P-value for the $\mathrm{H}$ factor. (A: autumn; S: spring; *: significant; **: highly significant; $* * *$ : very highly significant).

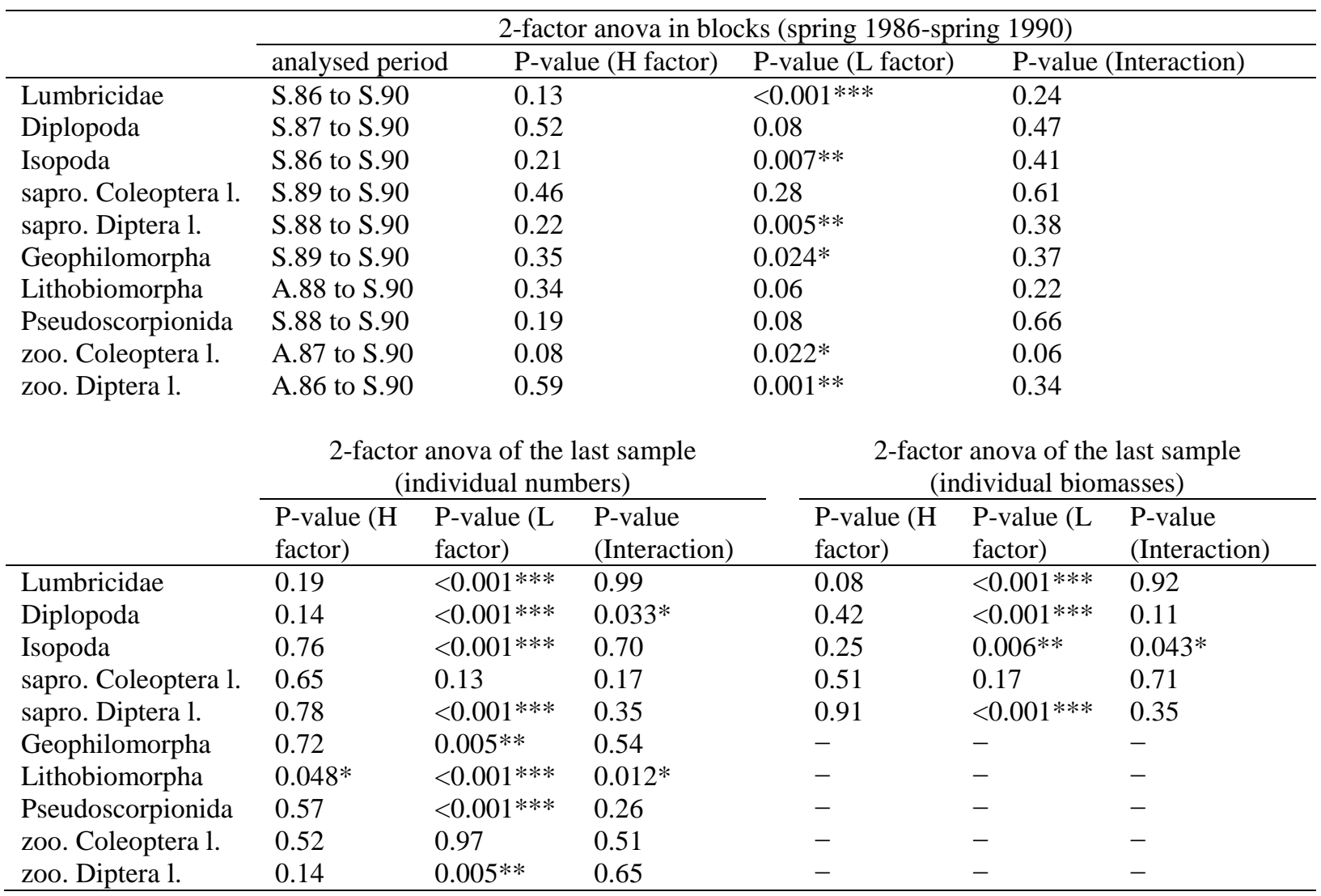


Table 4. Statistical analysis of abundances for three levels of litter supply (Lo, L-, L+). P is the probability that the sample means are from the same population. The analysed period is read from Fig. 2 or 3. (A: autumn; S: spring; *: significant; **: highly significant; ***: very highly significant).

\begin{tabular}{|c|c|c|c|c|}
\hline & \multicolumn{4}{|c|}{ 1-factor anova in blocks (spring 1986-spring 1990) } \\
\hline & analysed period & $\mathrm{P}$ value & \multicolumn{2}{|c|}{ significant $\neq$} \\
\hline Lumbricidae & A.86 or A.87 to $\mathrm{S} .90$ & $<0.001 * * *$ & \multicolumn{2}{|c|}{$[\mathrm{Lo}, \mathrm{L}+]>\mathrm{L}-$} \\
\hline Diplopoda & S. 88 to $S .90$ & $0.047 *$ & \multicolumn{2}{|c|}{$[\mathrm{Lo}, \mathrm{L}+]>\mathrm{L}-$} \\
\hline Isopoda & A.87 to $\mathrm{S} .90$ & $0.004 * *$ & \multicolumn{2}{|c|}{$[\mathrm{Lo}, \mathrm{L}+]>\mathrm{L}-$} \\
\hline sapro. Coleoptera 1. & A. 86 to $\mathrm{S} .90$ & $0.018 *$ & \multicolumn{2}{|c|}{$\mathrm{L}+>[\mathrm{Lo}, \mathrm{L}-]$} \\
\hline sapro. Diptera 1. & S. 88 to $\mathrm{S} .90$ & $0.001 * *$ & \multicolumn{2}{|c|}{$[\mathrm{Lo}, \mathrm{L}+]>\mathrm{L}-$} \\
\hline Geophilomorpha & S.88 or A. 88 to $\mathrm{S} .90$ & $<0.001 * * *$ & \multicolumn{2}{|c|}{$[\mathrm{Lo}, \mathrm{L}+]>\mathrm{L}-$} \\
\hline Lithobiomorpha & S.88 to $\mathrm{S} .90$ & $0.011^{*}$ & \multicolumn{2}{|c|}{$[\mathrm{Lo}, \mathrm{L}+]>\mathrm{L}-$} \\
\hline Pseudoscorpionida & $\mathrm{S} .87$ to $\mathrm{S} .90$ & $0.033^{*}$ & \multicolumn{2}{|c|}{$\mathrm{Lo}>\mathrm{L}+$} \\
\hline zoo. Coleoptera 1. & S.86 to $S .90$ & $0.003 * *$ & \multicolumn{2}{|c|}{$[\mathrm{Lo}, \mathrm{L}+]>\mathrm{L}-$} \\
\hline \multirow[t]{3}{*}{ zoo. Diptera 1.} & A. 87 to $\mathrm{S} .90$ & $0.003 * *$ & [Lo, & \\
\hline & \multicolumn{2}{|c|}{$\begin{array}{c}\text { 1-factor anova of the last sample } \\
\text { (individual numbers) }\end{array}$} & \multicolumn{2}{|c|}{$\begin{array}{l}\text { 1-factor anova of the last sample } \\
\text { (biomasses) }\end{array}$} \\
\hline & $\mathrm{P}$ value $\quad$ sig & cant $\neq$ & $\mathrm{P}$ value & significant $\neq$ \\
\hline Lumbricidae & $<0.001 * * *$ & $+]>\mathrm{L}-$ & $<0.001 * * *$ & {$[\mathrm{Lo}, \mathrm{L}+]>\mathrm{L}-$} \\
\hline Diplopoda & $<0.001 * * *$ & $+]>L-$ & $<0.001 * * *$ & {$[\mathrm{Lo}, \mathrm{L}+]>\mathrm{L}-$} \\
\hline Isopoda & $<0.001 * * *$ & $+]>L-$ & $0.001^{* *}$ & {$[\mathrm{Lo}, \mathrm{L}+]>\mathrm{L}-$} \\
\hline sapro. Coleoptera 1. & $0.028 *$ & & 0.25 & - \\
\hline sapro. Diptera 1. & $0.001 * *$ & $+]>L-$ & $<0.001 * * *$ & {$[\mathrm{Lo}, \mathrm{L}+]>\mathrm{L}-$} \\
\hline Geophilomorpha & $<0.001 * * *$ & $+]>L-$ & - & - \\
\hline Lithobiomorpha & $<0.001 * * *$ & $+]>L-$ & - & - \\
\hline Pseudoscorpionida & $<0.001 * * *$ & & - & - \\
\hline zoo. Coleoptera 1. & 0.45 & & - & - \\
\hline zoo. Diptera 1. & $0.018 *$ & & - & - \\
\hline
\end{tabular}


目 Zoophages D Saprophages

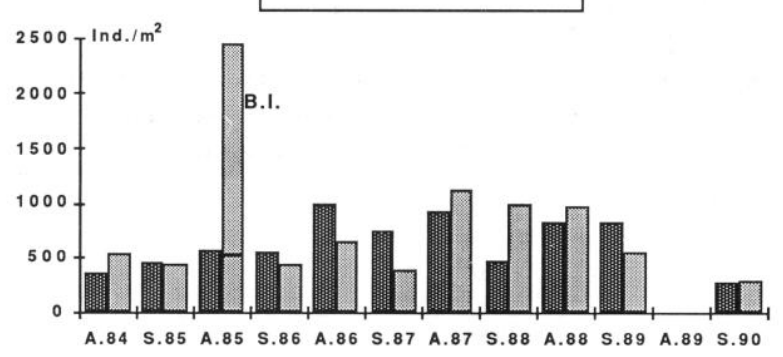

Fig. 1 
24
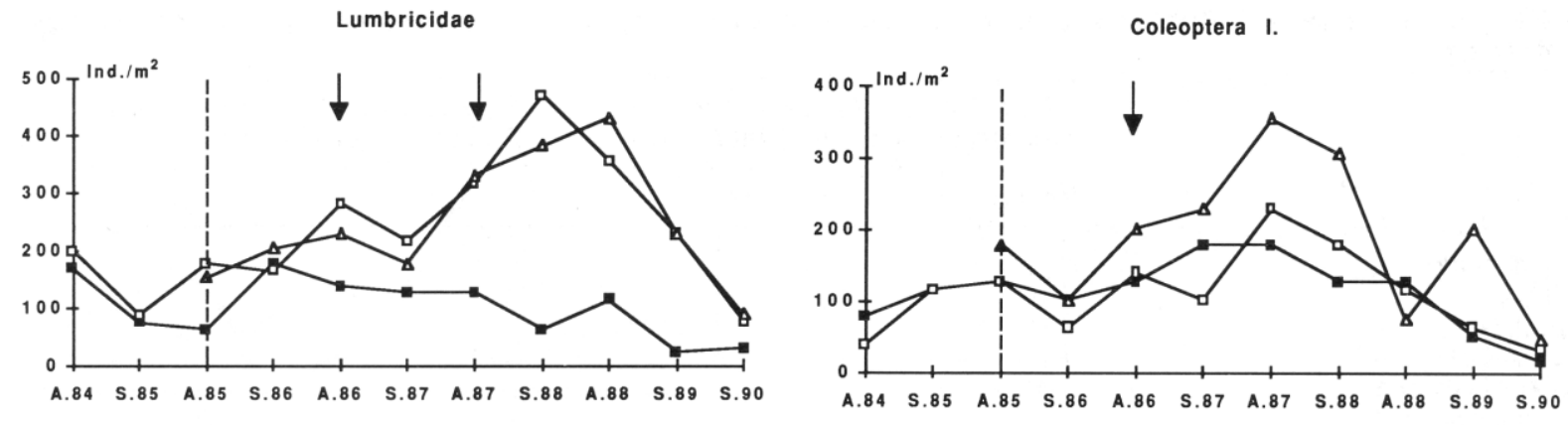

Diplopoda Diptera I.
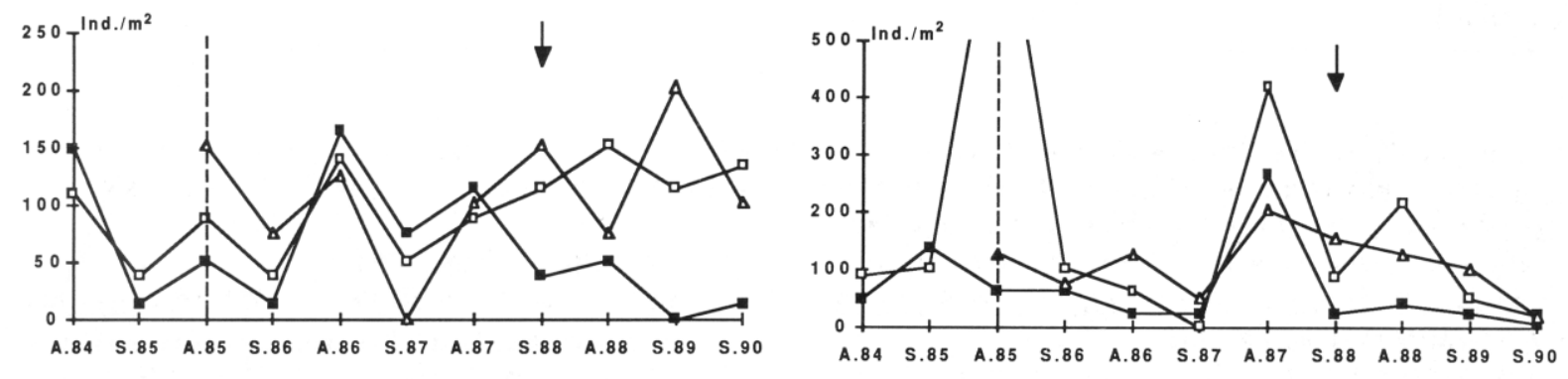

Isopoda

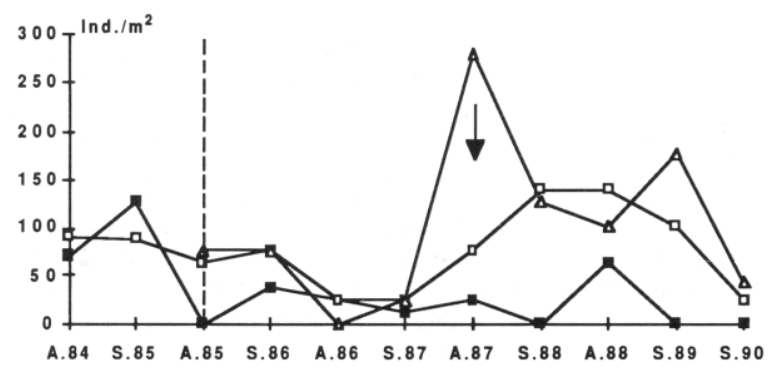

Fig. 2 
25

Geophilomorpha

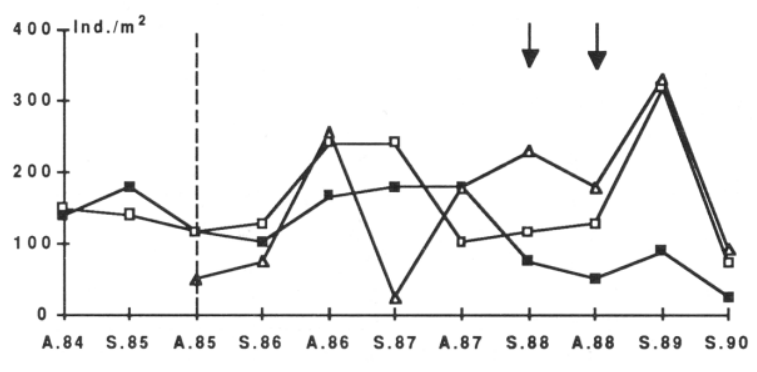

Lithobiomorpha

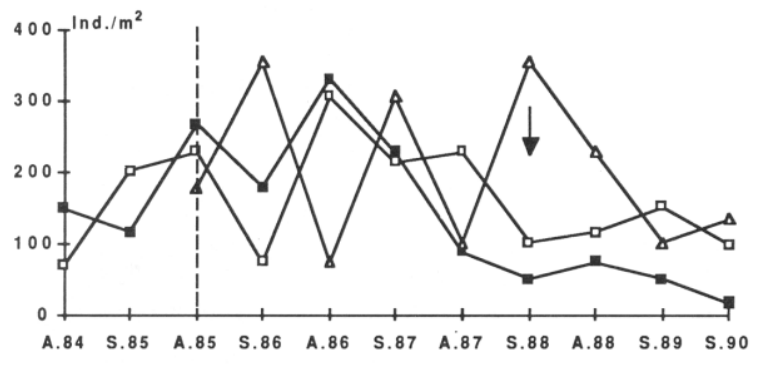

Pseudoscorpionida

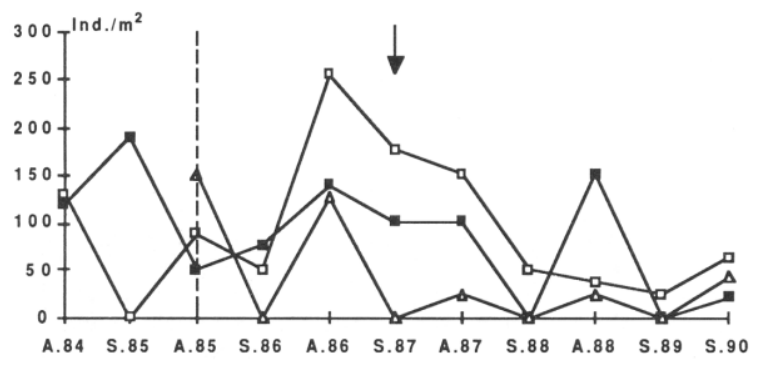

Fig. 3
Coleoptera I.

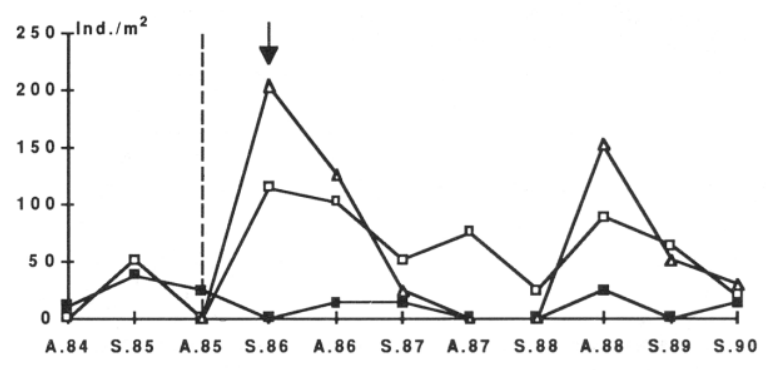

Diptera I.

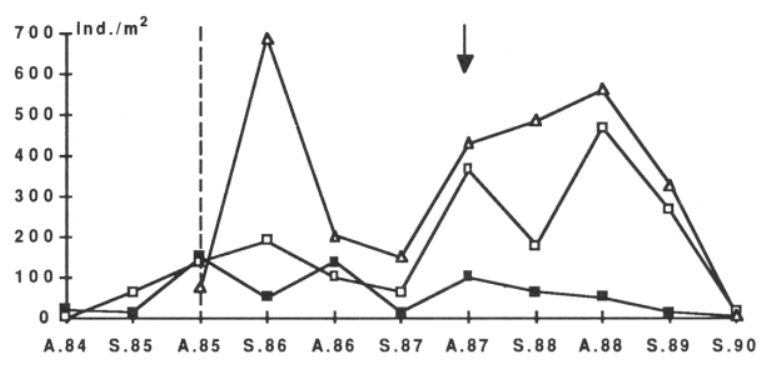

